Article

\title{
Formamido-Diterpenes from the South China Sea Sponge Acanthella cavernosa
}

\author{
Ying Xu ${ }^{1,2}$, Jun-Hui Lang ${ }^{1}$, Wei-Hua Jiao ${ }^{1}$, Ru-Ping Wang ${ }^{1,2}$, Ying Peng ${ }^{2}$, \\ Shao-Jiang Song ${ }^{2, *}$, Bao-Hua Zhang ${ }^{3, *}$ and Hou-Wen Lin ${ }^{1, *}$
}

1 Laboratory of Marine Drugs, Department of Pharmacy, Changzheng Hospital, Second Military Medical University, Shanghai 200003, China; E-Mails: xy30490@126.com (Y.X.); zhenshanmei.hui@163.com (J.-H.L.); weihuajiao@hotmail.com (W.-H.J.); wangruping_sy@yahoo.com.cn (R.-P.W.)

2 College of Traditional Chinese Materia Medica, Shenyang Pharmaceutical University, Shenyang 110016, China; E-Mail: yingpeng1999@yahoo.com.cn

3 Eastern Hepatobiliary Surgical Hospital, Second Military Medical University, Shanghai 200438, China

* Authors to whom correspondence should be addressed; E-Mails: songsj99@yahoo.com.cn (S.-J.S.); zhbh_1@tom.com (B.-H.Z.); franklin67@126.com (H.-W.L.); Tel./Fax: +86-24-23986510 (S.-J.S.); +86-21-81875272 (B.-H.Z.); +86-21-65585154 (H.-W.L.).

Received: 15 May 2012; in revised form: 1 June 2012 / Accepted: 16 June 2012 /

Published: 2 July 2012

\begin{abstract}
Seven new formamido-diterpenes, cavernenes A-D (1-4), kalihinenes E and F (5-6), and kalihipyran C (7), together with five known compounds (8-12), were isolated from the South China Sea sponge Acanthella cavernosa. Structures were established using IR, HRESIMS, 1D and 2D NMR, and single X-ray diffraction techniques. The isolated compounds were assessed for their cytotoxicity against a small panel of human cancer cell lines (HCT-116, A549, HeLa, QGY-7701, and MDA-MB-231) with $\mathrm{IC}_{50}$ values in the range of $6-18 \mu \mathrm{M}$. In addition, compound 9 showed weak antifungal activity against Trichophyton rubrum and Microsporum gypseum with MIC values of 8 and $32 \mu \mathrm{g} / \mathrm{mL}$, respectively, compound $\mathbf{1 0}$ displayed weak antifungal activity against fungi Candida albicans, Cryptococcus neoformans, T. rubrum, and M. gypseum with MIC values of $8,8,4$, and $8 \mu \mathrm{g} / \mathrm{mL}$, respectively.
\end{abstract}

Keywords: Acanthella cavernosa; formamido-diterpenes; cytotoxicity; antifungal activity 


\section{Introduction}

Marine sponges of the genus Acanthella have proven to be a rich source of new diterpenes and sesquiterpenes containing nitrogenous functional groups, including isonitrile $(-\mathrm{NC})$, isothiocyanate (-NCS), isocyanate (-NCO), and formamide (-NHCHO) functionalities, which show various promising biological activities [1-7]. Diterpenes isolated from this genus have demonstrated cytotoxic [8], anthelmintic [9,10], antimalarial [11], antimicrobial [12], antifungal [1,13,14], and antifouling activities [15-17]. In general, these diterpenes can be divided into two types, defined by having a trans- or cis-decalin moiety. The diterpene precursor has been supposed to be geranylgeraniol, which cyclizes to form a cis- or trans-biflorane skeleton [6]. In our previous study, we had reported the isolation of eight new diterpenes, kalihinols $\mathrm{M}-\mathrm{T}$, together with seven known compounds from the $\mathrm{CH}_{2} \mathrm{Cl}_{2}$ extract of the sponge A. cavernosa [18]. As part of our interest on bioactive secondary metabolites from the marine sponges of the genus Acanthella, a petroleum ether extract of A. cavernosa was investigated and found to be cytotoxic. Further bioassay-guided fractionation of the extract led to the isolation of 12 formamido-diterpenes (1-12), including seven new ones (1-7) (Figure 1). Details of the isolation, structure elucidation, cytotoxic and antifungal activities of these compounds are described herein.

Figure 1. Structures 1-12 isolated from Acanthella cavernosa.

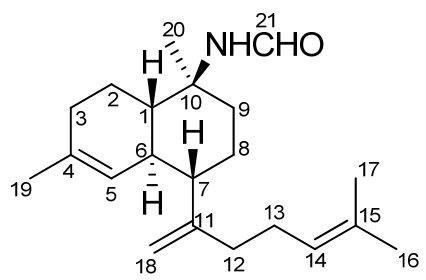

1

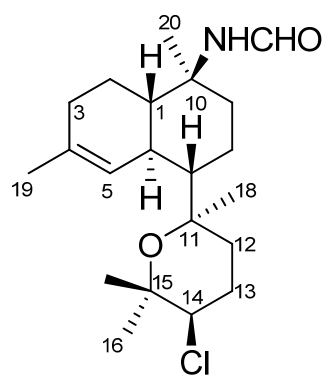

5

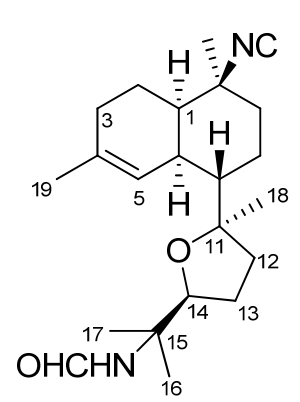

9

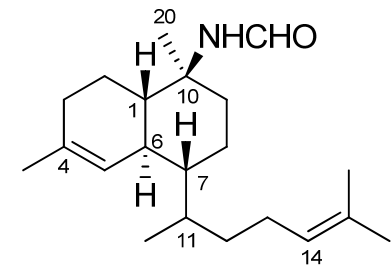

2

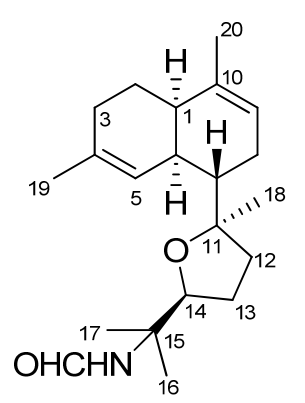

6

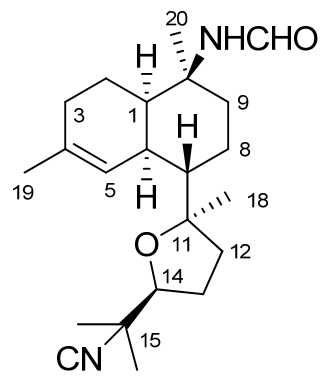

10

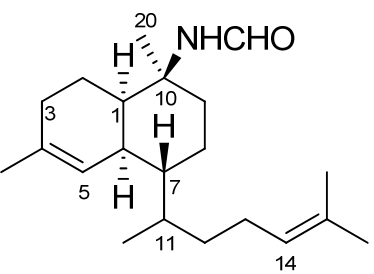

3

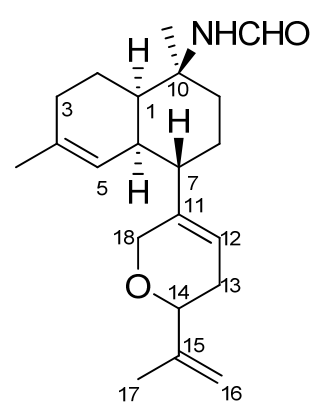

7

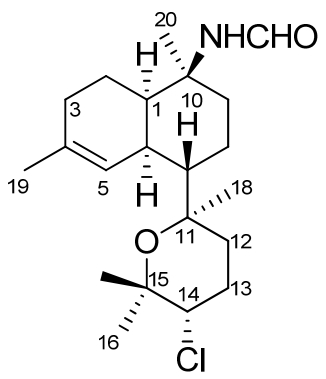

11

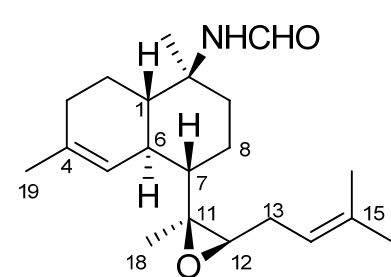

4

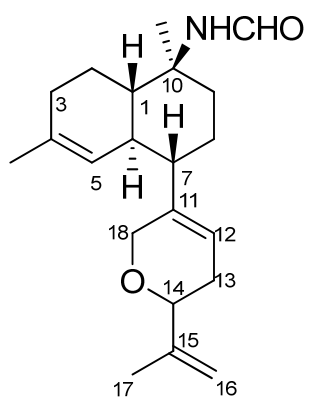

8

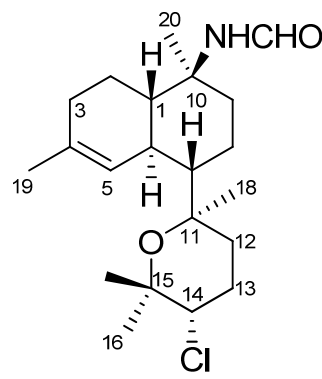

12 


\section{Results and Discussion}

The sponge $A$. cavernosa was exhaustively extracted with acetone, and after being subjected to extensive column chromatography on silica gel, Sephadex LH-20, ODS, and semipreparative HPLC, compounds 1-12 were obtained. The known compounds, kalihipyran A (8) [16], 15-formamido-kalihinene (9) [6], 10-formamido-kalihinene (10) [6], and kalihinenes X (11) and Y (12) [15], were identified by comparison of their spectroscopic data with literature values.

In the ${ }^{1} \mathrm{H}$ and ${ }^{13} \mathrm{C}$ NMR spectra of compounds $1-7$, most signals were doubled in the ratio of $\sim 1.8: 1,2.2: 1,1.1: 1,1.4: 1,2.1: 1,1.9: 1$, and 1.1:1, respectively. This suggested that $1-7$ existed as equilibrium mixtures derived from the s-trans and s-cis forms of formamide groups, as in the cases of 8-12 [6,15,16], which was supported by IR absorptions $(\mathbf{1}, 1670 ; \mathbf{2}, 1681 ; \mathbf{3}, \mathbf{1 6 6 8 ; 4}, \mathbf{1 6 8 1} \mathbf{5}, \mathbf{1 6 8 2}$; 6, 1686; and 7, $1668 \mathrm{~cm}^{-1}$ ) [16]. The assignments of the formamide groups ( $\mathrm{NH}$ and $\mathrm{CHO}$ ) in $\mathbf{1}-\mathbf{7}$ for s-trans isomers and s-cis isomers were confirmed by HSQC and COSY data (Tables 1 and 2).

Table 1. ${ }^{1} \mathrm{H}$ NMR data of compounds $1-7\left(\mathrm{CDCl}_{3}, J\right.$ in $\left.\mathrm{Hz}\right)$.

\begin{tabular}{|c|c|c|c|c|c|c|c|}
\hline Position & $1^{a, c}$ & $2^{b, c}$ & $3^{a, c}$ & $4^{a, c}$ & $5^{b, c}$ & $6^{a, c}$ & $7^{a, d}$ \\
\hline 1 & $1.24 \mathrm{~m}$ & $1.26 \mathrm{~m}^{e}$ & $1.65 \mathrm{~m}^{e}$ & $1.30 \mathrm{~m}^{e}$ & $1.30 \mathrm{~m}$ & $1.96 \mathrm{~m}$ & $2.40 \mathrm{~m}$ \\
\hline $2 \mathrm{a}$ & $1.84 \mathrm{~m}$ & $1.34 \mathrm{~m}$ & $1.73 \mathrm{~m}$ & $1.85 \mathrm{~m}$ & $1.84 \mathrm{~m}^{e}$ & $1.87 \mathrm{~m}$ & $1.48 \mathrm{~m}^{e}$ \\
\hline $2 b$ & $1.30 \mathrm{~m}$ & $1.26 \mathrm{~m}^{e}$ & $1.65 \mathrm{~m}^{e}$ & $1.30 \mathrm{~m}^{e}$ & $1.28 \mathrm{~m}$ & $1.48 \mathrm{~m}$ & $1.48 \mathrm{~m}^{e}$ \\
\hline $3 a$ & $1.99 \mathrm{~m}^{e}$ & $1.97 \mathrm{~m}^{e}$ & $1.99 \mathrm{~m}^{e}$ & $2.00 \mathrm{~m}^{e}$ & $1.93 \mathrm{~m}^{e}$ & $2.01 \mathrm{~m}$ & $2.00 \mathrm{~m}^{e}$ \\
\hline $3 b$ & $1.99 \mathrm{~m}^{e}$ & $1.97 \mathrm{~m}^{e}$ & $1.99 \mathrm{~m}^{e}$ & $2.00 \mathrm{~m}^{e}$ & $1.93 \mathrm{~m}^{e}$ & $1.89 \mathrm{~m}$ & $2.00 \mathrm{~m}^{e}$ \\
\hline 5 & 5.24 br s & 5.47 br s & 5.49 br d (4.0) & 5.69 br s & 6.37 br s & 5.70 br s & 5.39 br s \\
\hline 6 & $2.05 \mathrm{~m}$ & $1.91 \mathrm{~m}$ & $2.15 \mathrm{~m}$ & $2.18 \mathrm{~m}$ & $2.11 \mathrm{~m}$ & $2.20 \mathrm{~m}$ & $2.20 \mathrm{~m}$ \\
\hline 7 & $1.73 \mathrm{~m}$ & $1.14 \mathrm{~m}$ & $1.43 \mathrm{~m}^{e}$ & $1.17 \mathrm{~m}$ & $1.58 \mathrm{~m}$ & $1.62 \mathrm{~m}$ & $1.78 \mathrm{~m}^{e}$ \\
\hline $8 \mathrm{a}$ & $1.66 \mathrm{~m}$ & $1.53 \mathrm{~m}$ & $1.43 \mathrm{~m}^{e}$ & $1.43 \mathrm{~m}$ & $1.10 \mathrm{~m}$ & $1.74 \mathrm{~m}$ & $1.55 \mathrm{~m}^{e}$ \\
\hline $8 \mathrm{~b}$ & $1.50 \mathrm{~m}$ & $1.26 \mathrm{~m}$ & $1.26 \mathrm{~m}$ & $1.57 \mathrm{~m}$ & $1.75 \mathrm{~m}$ & $1.94 \mathrm{~m}$ & $1.55 \mathrm{~m}^{e}$ \\
\hline $9 \mathrm{a}$ & $1.89 \mathrm{~m}$ & $1.88 \mathrm{~m}$ & $1.65 \mathrm{~m}^{e}$ & $1.90 \mathrm{dt}(9.5,3.5)$ & $1.89 \mathrm{~m}$ & \multirow{3}{*}{5.32 br s } & $1.55 \mathrm{~m}^{e}$ \\
\hline $9 b$ & $1.62 \mathrm{~m}^{e}$ & $1.56 \mathrm{~m}$ & $1.55 \mathrm{~m}^{e}$ & $1.60 \mathrm{~m}$ & $1.62 \mathrm{~m}$ & & $1.55 \mathrm{~m}^{e}$ \\
\hline 11 & & $1.97 \mathrm{~m}^{e}$ & $1.75 \mathrm{~m}$ & & & & \\
\hline $12 \mathrm{a}$ & $1.99 \mathrm{~m}^{e}$ & $1.26 \mathrm{~m}^{e}$ & $1.24 \mathrm{~m}^{e}$ & \multirow{2}{*}{$2.62 \mathrm{t}(6.5)$} & $1.28 \mathrm{~m}^{e}$ & $1.78 \mathrm{~m}$ & \multirow{2}{*}{$5.61 \mathrm{~m}^{e}$} \\
\hline $12 b$ & $1.99 \mathrm{~m}^{e}$ & $1.26 \mathrm{~m}^{e}$ & $1.24 \mathrm{~m}^{e}$ & & $1.28 \mathrm{~m}^{e}$ & $1.63 \mathrm{~m}$ & \\
\hline $13 \mathrm{a}$ & $2.13 \mathrm{~m}$ & $1.97 \mathrm{~m}^{e}$ & $1.99 \mathrm{~m}^{e}$ & $2.23 \mathrm{~m}^{e}$ & $2.27 \mathrm{~m}$ & $1.83 \mathrm{~m}$ & $2.18 \mathrm{~m}$ \\
\hline $13 b$ & $1.99 \mathrm{~m}^{e}$ & $1.97 \mathrm{~m}^{e}$ & $1.90 \mathrm{~m}$ & $2.23 \mathrm{~m}^{e}$ & $1.97 \mathrm{~m}$ & $1.56 \mathrm{~m}$ & $2.13 \mathrm{~m}$ \\
\hline 14 & $5.13 \mathrm{t}(5.5)$ & $5.11 \mathrm{t}(6.0)$ & 5.08 br s & $5.19 \mathrm{t}(6.5)$ & $3.93 \mathrm{~m}$ & $3.75 \mathrm{t}(7.0)$ & 3.89 br s \\
\hline 16 & $1.69 \mathrm{~s}$ & $1.69 \mathrm{~s}$ & $1.67 \mathrm{~s}$ & $1.72 \mathrm{~s}$ & $1.39 \mathrm{~s}$ & $1.31 \mathrm{~s}$ & $\begin{array}{l}4.88 \mathrm{~s} \\
5.01 \mathrm{~s}\end{array}$ \\
\hline 17 & $1.62 \mathrm{~s}^{e}$ & $1.60 \mathrm{~s}$ & $1.59 \mathrm{~s}$ & $1.62 \mathrm{~s}$ & $1.31 \mathrm{~s}$ & $1.20 \mathrm{~s}$ & $1.78 \mathrm{~s}^{e}$ \\
\hline 18 & $\begin{array}{l}4.89 \text { br s } \\
4.80 \text { br s }\end{array}$ & $0.78 \mathrm{~d}(6.9)$ & $0.83 \mathrm{~d}(6.5)$ & $1.26 \mathrm{~s}$ & $1.22 \mathrm{~s}^{e}$ & $1.18 \mathrm{~s}$ & $\begin{array}{l}4.16 \mathrm{br} \mathrm{s}^{e} \\
4.16 \mathrm{br} \mathrm{s}^{e}\end{array}$ \\
\hline 19 & $1.62 \mathrm{~s}^{e}$ & $1.67 \mathrm{~s}$ & $1.65 \mathrm{~s}^{e}$ & $1.68 \mathrm{~s}$ & $1.65 \mathrm{~s}$ & $1.68 \mathrm{~s}$ & $1.62 \mathrm{~s}$ \\
\hline 20 & $1.28 \mathrm{~s}$ & $1.22 \mathrm{~s}$ & $1.43 \mathrm{~s}^{e}$ & $1.27 \mathrm{~s}$ & $1.22 \mathrm{~s}^{e}$ & $1.68 \mathrm{~s}$ & $1.55 \mathrm{~s}^{e}$ \\
\hline $\mathrm{NH}$ & $5.89 \mathrm{~d}(12.5)$ & $6.10 \mathrm{~d}(11.8)$ & $5.62 \mathrm{~d}(12.0)$ & $5.92 \mathrm{~d}(12.0)$ & $5.66 \mathrm{~d}(12.5)$ & $5.86 \mathrm{~m}$ & $5.61 \mathrm{~m}^{e}$ \\
\hline $\mathrm{CHO}$ & $8.30 \mathrm{~d}(12.0)$ & $8.27 \mathrm{~d}(12.3)$ & $8.24 \mathrm{~d}(12.5)$ & $8.29 \mathrm{~d}(12.5)$ & $8.28 \mathrm{~d}(12.5)$ & $8.19 \mathrm{~d}(12.5)$ & $8.08 \mathrm{~d}(2.0)$ \\
\hline
\end{tabular}

${ }^{a}$ Measured at $500 \mathrm{MHz} ;{ }^{b}$ Measured at $400 \mathrm{MHz} ;{ }^{c}$ Data for major s-trans isomer; ${ }^{d}$ Data for major s-cis isomer; ${ }^{e}$ Overlapped. 
Cavernene A (1) was isolated as a colorless oil. A molecular formula of $\mathrm{C}_{21} \mathrm{H}_{33} \mathrm{ON}$ was established by the $[\mathrm{M}+\mathrm{Na}]^{+}$ion peak at $m / z 338.2461$ in the HRESIMS and supported by NMR data (Tables 1 and 2), indicating six degrees of unsaturation. The ${ }^{1} \mathrm{H}$ NMR spectrum showed the presence of four tertiary methyl $\left[\delta_{\mathrm{H}} 1.28(3 \mathrm{H}, \mathrm{s}), 1.62(6 \mathrm{H}, \mathrm{s})\right.$, and $\left.1.69(3 \mathrm{H}, \mathrm{s})\right]$ and four olefinic proton signals resonated at $\delta_{\mathrm{H}} 4.80\left(1 \mathrm{H}\right.$, br s), $4.89\left(1 \mathrm{H}\right.$, br s), $5.13(1 \mathrm{H}, \mathrm{t}, J=5.5 \mathrm{~Hz})$, and $5.24\left(1 \mathrm{H}\right.$, br s). The ${ }^{13} \mathrm{C} \mathrm{NMR}$ and DEPT spectra of 1 displayed 21 carbon resonances for four methyls, seven methylenes (one olefinic), six methines (two olefinic and one formamido), and four quaternary carbons (three olefinic). The above moieties accounted for four of six degrees of unsaturation, indicating a bicyclic structure for 1. The COSY correlations of $\mathrm{H}-9 / \mathrm{H}-8 / \mathrm{H}-7 / \mathrm{H}-6 / \mathrm{H}-1 / \mathrm{H}-2 / \mathrm{H}-3 / \mathrm{H}-5 / \mathrm{H}-19$, together with the $\mathrm{HMBC}$ correlations of $\mathrm{H}_{3}-19 / \mathrm{C}-3$, C-4, and C-5, $\mathrm{H}_{3}-20 / \mathrm{C}-1$, C-9, and C-10, H-5/C-1, C-3, C-6, and C-7, and $\mathrm{CHO} / \mathrm{C}-10$ indicated the presence of a decalin moiety (Figure 2). The HMBC correlations from the geminal methyls $\left(\mathrm{H}_{3}-16\right.$ and $\left.\mathrm{H}_{3}-17\right)$ to $\mathrm{C}-14$ and $\mathrm{C}-15$, from terminal olefinic protons $\left(\mathrm{H}_{2}-18\right)$ to $\mathrm{C}-7$, C-11, and C-12, and from H-13 to C-11, C-12, C-14, and C-15 and COSY correlation between H-13 and $\mathrm{H}-14$ revealed the presence of an isoprenoid unit homolog in $\mathbf{1}$ and connectivity of the two moieties between $\mathrm{C}-12$ and C-7 through the quaternary carbon C-11.

Table 2. ${ }^{13} \mathrm{C}$ NMR data $\left(\mathrm{CDCl}_{3}, \delta\right.$ in ppm) of compounds $\mathbf{1}-\mathbf{7}$.

\begin{tabular}{|c|c|c|c|c|c|c|c|c|c|c|c|c|c|c|}
\hline \multirow{2}{*}{ C } & \multicolumn{2}{|c|}{$1^{a}$} & \multicolumn{2}{|c|}{$2^{b}$} & \multicolumn{2}{|c|}{$3^{a}$} & \multicolumn{2}{|c|}{$4^{a}$} & \multicolumn{2}{|c|}{$5^{b}$} & \multicolumn{2}{|c|}{$6^{a}$} & \multicolumn{2}{|c|}{$7^{a}$} \\
\hline & s-trans & s-cis & s-trans & $\mathrm{s}-c i s$ & s-trans & s-cis & s-trans & $\mathrm{s}-c i s$ & s-trans & s-cis & s-trans & s-cis & s-cis & s-trans \\
\hline 1 & 48.8 & 45.3 & 49.0 & 45.7 & 45.6 & 41.1 & 48.4 & 45.0 & 48.8 & 46.1 & 40.1 & 40.1 & 40.9 & 45.4 \\
\hline 2 & 22.8 & 23.1 & 22.9 & 23.4 & 19 & 19.5 & 22.7 & 23.1 & 23.3 & 23.7 & 24.6 & 24.7 & 18.8 & 19.1 \\
\hline 3 & 30.96 & 31.04 & 30.8 & 30.9 & 31.3 & 31.4 & 30.8 & 30.9 & 30.5 & 30.6 & 30.5 & 30.6 & 31.1 & 31.2 \\
\hline 4 & 134.4 & 134.1 & 134.9 & 134.6 & 134.3 & 134.2 & 134.8 & 134.3 & 132.4 & 131.9 & 131.1 & 130.8 & 134.5 & 134.4 \\
\hline 5 & 123.3 & 123.8 & 121.8 & 122.3 & 124.3 & 124.0 & 122.3 & 122.7 & 125.7 & 126.2 & 127.1 & 127.3 & 123.9 & 124.2 \\
\hline 6 & 39.5 & 39.4 & 38.4 & 38.2 & 35.2 & 34.8 & 38.6 & 38.4 & 39.5 & 39.2 & 36.5 & 36.5 & 37.0 & 36.5 \\
\hline 7 & 50.3 & 50.3 & 44.6 & 44.4 & 42.3 & 42.0 & 45.2 & 45.2 & 51.2 & 50.4 & 44.9 & 45.2 & 43.3 & 43.6 \\
\hline 8 & 29.7 & 29.9 & 20.9 & 20.9 & & 19.9 & 25.7 & 25.8 & & 24.7 & 29.48 & 29.51 & 28.4 & 28.4 \\
\hline 9 & 42.0 & 37.6 & 41.8 & 37.4 & 33.0 & 33.7 & 41.7 & 37.3 & 42.1 & 37.8 & 120.2 & 120.5 & 33.5 & 32.8 \\
\hline 10 & 55.5 & 57.2 & 55.6 & 57.3 & 55.5 & 57.1 & 55.3 & 56.8 & 55.4 & 56.9 & 136.9 & 136.8 & 56.8 & 55.4 \\
\hline 11 & 151.3 & 151.9 & 30.8 & 30.8 & 31.3 & 31.1 & 62.33 & 62.7 & 76.9 & 77.2 & 86.4 & 86.3 & 139.4 & 139.0 \\
\hline 12 & 34.2 & 34.2 & 35.65 & 35.69 & 35.7 & 35.8 & 62.27 & 62.33 & 31.0 & 31.7 & 37.2 & 37.1 & 118.6 & 118.9 \\
\hline 13 & 26.3 & 26.3 & 26.2 & 26.2 & 26.2 & 26.3 & 27.0 & 27.0 & 25.9 & 26.1 & 25.6 & 25.8 & 29.6 & 29.6 \\
\hline 14 & 124.2 & 124.3 & 124.6 & 124.8 & 124.7 & 124.9 & 119.3 & 119.5 & 64.2 & 64.5 & 84.2 & 84.5 & 77.2 & 76.8 \\
\hline 15 & 131.7 & 131.6 & 131.3 & 131.1 & 131.2 & 131.1 & 134.2 & 134.1 & 74.2 & 74.4 & 54.5 & 55.9 & 145.4 & 145.3 \\
\hline 16 & 25.7 & 25.7 & 25.7 & 25.7 & 25.7 & 25.7 & 25.7 & 25.7 & 29.7 & 29.7 & 27.4 & 25.1 & 110.5 & 110.6 \\
\hline 17 & 17.8 & 17.8 & 17.7 & 17.7 & 17.7 & 17.7 & 18.0 & 18.0 & 28.9 & 28.4 & 23.8 & 21.7 & 18.9 & 18.9 \\
\hline 18 & 110.0 & 109.6 & 13.3 & 13.3 & 13.3 & 13.3 & 18.5 & 18.5 & 21.9 & 21.2 & 20.3 & 21.1 & 67.63 & 67.58 \\
\hline 19 & 23.3 & 23.4 & 23.6 & 23.7 & 23.5 & 23.4 & 23.55 & 23.60 & 23.8 & 23.8 & 23.92 & 23.87 & 23.3 & 23.4 \\
\hline 20 & 19.0 & 18.9 & 18.8 & 18.7 & 27.2 & 23.7 & 18.9 & 18.7 & 19.0 & 18.5 & 21.53 & 21.47 & 23.6 & 29.7 \\
\hline 21 & 162.8 & 160.4 & 163.1 & 160.5 & 162.8 & 160.0 & 162.8 & 160.4 & 162.7 & 160.4 & 163.1 & 160.9 & 160.1 & 162.8 \\
\hline
\end{tabular}

The relative configuration of $\mathbf{1}$ was established on the basis of NOESY data (Figure 2). The NOESY correlations of $\mathrm{H}-1 / \mathrm{H}-7$ and NH/H-1 indicated that these protons were on the same face of the 
decalin ring and arbitrarily assigned $\beta$-orientations. The $\alpha$-orientation of $\mathrm{H}-6$ was determined by the NOESY correlation between $\mathrm{H}_{3}-20$ and $\mathrm{H}-6$. In addition, the carbon resonances at $\delta_{\mathrm{C}} 48.8(\mathrm{C}-1)$, 39.5 (C-6), 42.0 (C-9), and 19.0 (C-20) in 1 further confirmed the trans fusion of the decalin ring [6,8,15]. Cavernene A (1) can be envisaged as a decomposable intermediate product of isocyanobifloradiene epoxides in the plausible biogenetic pathway of kalihiprans $[3,19]$.

Figure 2. COSY (-), key HMBC $(\rightarrow)$, and key NOESY correlations of $\mathbf{1}$.
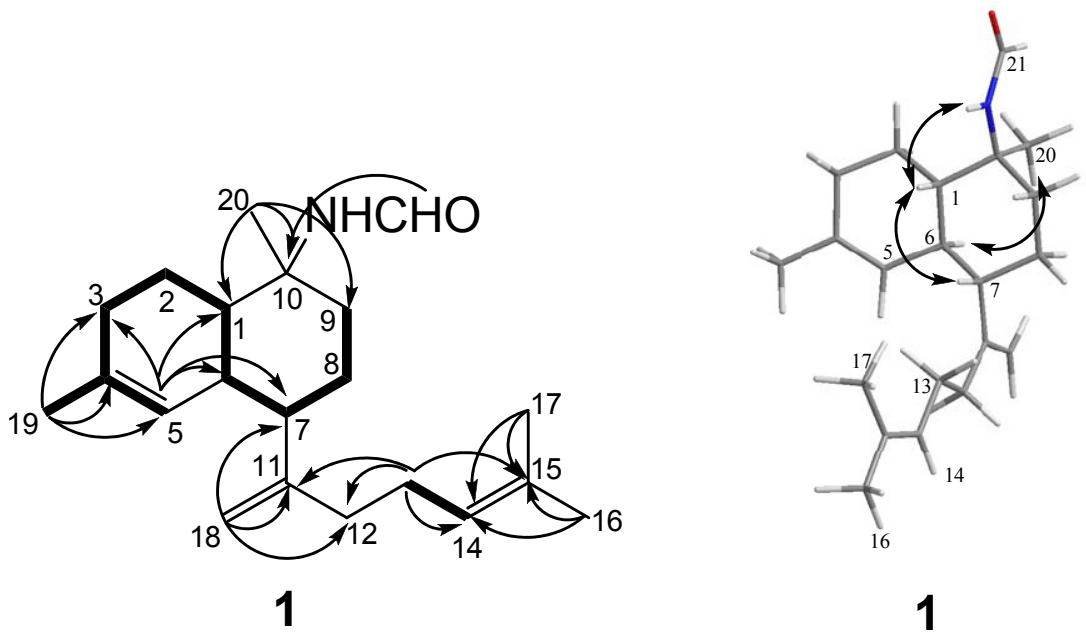

Cavernene B (2) was obtained as a colorless oil. Its molecular formula of $\mathrm{C}_{21} \mathrm{H}_{35} \mathrm{ON}$ was deduced from the HRESIMS $\left(\mathrm{m} / \mathrm{z} 340.2617[\mathrm{M}+\mathrm{Na}]^{+}\right)$combined with its NMR data (Tables 1 and 2), indicating five degrees of unsaturation. The ${ }^{1} \mathrm{H}$ and ${ }^{13} \mathrm{C}$ NMR spectra of $\mathbf{1}$ and $\mathbf{2}$ were comparable except for a marked difference in the isoprenoid unit. Signals for a C-11-C-18 double bond were absent in 2 and replaced by saturated carbons resonated at $\delta_{\mathrm{C}} 30.8$ and 13.3, respectively. The HMBC correlations of $\mathrm{H}_{3}-18 / \mathrm{C}-7, \mathrm{C}-11$, and $\mathrm{C}-12$ and the COSY correlations of $\mathrm{H}_{3}-18 / \mathrm{H}-11 / \mathrm{H}-12$ and $\mathrm{H}-11 / \mathrm{H}-7$ supported the assignment of convernene $\mathrm{B}$ as $\mathbf{2}$. The relative configuration of the decalin ring in $\mathbf{2}$ was the same as in 1, with the observation of the NOESY correlations of NH/H-1, $\mathrm{H}_{3}-20 / \mathrm{H}-6$, $\mathrm{NH} / \mathrm{H}-9 \mathrm{~b}, \mathrm{H}-7 / \mathrm{H}-9 \mathrm{~b}$, and $\mathrm{H}_{3}-20 / \mathrm{H}-9 \mathrm{a}$ (Supporting Information). The relative configuration at C-11, however, could not be conclusively determined due to conformational flexibility between C-7 and C-11.

Cavernene C (3), obtained as white needles, showed the same molecular formula of $\mathrm{C}_{21} \mathrm{H}_{35} \mathrm{ON}$ as 2 determined by pseudomolecular $[\mathrm{M}+\mathrm{Na}]^{+}$ion peak at $m / z$ 340.2614 in HRESIMS. Its carbon skeleton was readily assignable as the same as $\mathbf{2}$ by HSQC, HMBC, and COSY spectra. In particular, the carbon resonances of the isoprenoid unit in $\mathbf{3}$ were almost superimposable on those of $\mathbf{2}$ (Table 2), suggesting the same stereostructure of the isoprenoid unit for both $\mathbf{2}$ and 3. On the other hand, differences were observed for the signals of the decalin ring. Specifically, the carbon resonances at $\delta_{\mathrm{C}} 49.0(\mathrm{C}-1)$, 38.4 (C-6), 41.8 (C-9), and $18.8(\mathrm{C}-20)$ in 2 were replaced by resonances at $\delta_{\mathrm{C}} 45.6,35.2,33.0$, and 27.2 in 3 , respectively, indicating a cis fusion of the decalin ring $[6,8,15]$. The relative configuration at $\mathrm{C}-11$, however, could not be conclusively determined due to the free rotation around the C-7-C-11 bond.

Cavernene D (4) displayed a HRESIMS $[\mathrm{M}+\mathrm{Na}]^{+}$peak at $\mathrm{m} / \mathrm{z} 354.2407$ corresponding to a molecular formula of $\mathrm{C}_{21} \mathrm{H}_{33} \mathrm{O}_{2} \mathrm{~N}$, implying six degrees of unsaturation. Many similarities of the ${ }^{1} \mathrm{H}$ and ${ }^{13} \mathrm{C}$ NMR data between 2 and 4 (Tables 1 and 2) suggested they were structural analogs, with the main differences due to the presence of a trisubstituted epoxide $\left(\delta_{\mathrm{C}} 62.33\right.$ and 62.27$)$ in 4 and the 
absence of two saturated carbons $\left(\delta_{\mathrm{C}} 30.8\right.$ and 35.65$)$ in 2. The $\mathrm{C}-11 / \mathrm{C}-12$ position of the epoxy group was determined by a COSY correlation of $\mathrm{H}-12 / \mathrm{H}-13$ and $\mathrm{HMBC}$ correlations of $\mathrm{H}_{3}-18 / \mathrm{C}-7$, C-11, and C-12 and H-13/C-11 and C-12. The relative configuration of the decalin ring of 4, found to agree with 2 , was established by observation of NOESY correlations of NH/H-1, H-1/H-7, and $\mathrm{H}_{3}-20 / \mathrm{H}-6$. The relative configurations of $\mathrm{C}-7$ and $\mathrm{C}-11$ between the conjoined bicyclic ring systems in 4 were assigned as $7 S^{*}$ and $11 S^{*}$, respectively, based on NOESY correlations of $\mathrm{H}_{3}-18 / \mathrm{H}-6, \mathrm{H}_{3}-18 / \mathrm{H}-8 \mathrm{~b}$, and $\mathrm{H}-8 \mathrm{a} / \mathrm{H}-13$, as shown in the Newman projection (Figure 3). Thus, the epoxy group was determined as in $\beta$-orientation.

Figure 3. Key NOESY correlations of 4.

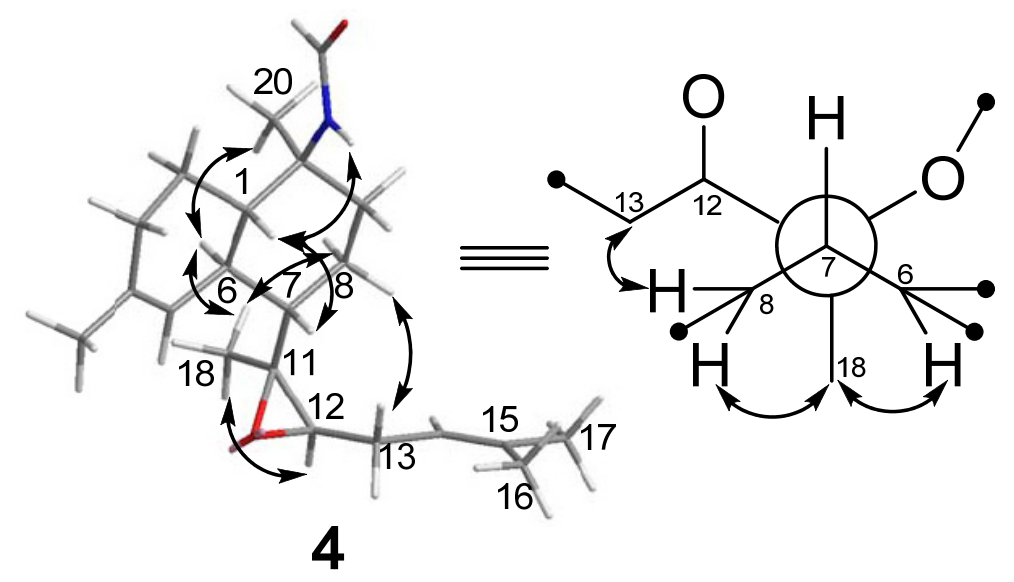

Kalihinene E (5) was isolated as colorless needles $(\mathrm{MeOH})$, and given a $\mathrm{C}_{21} \mathrm{H}_{34} \mathrm{NO}_{2} \mathrm{Cl}$ molecular formula with five degrees of unsaturation, based on the HRESIMS $\left(m / z 368.2354[\mathrm{M}+\mathrm{H}]^{+}\right)$and NMR spectra. The ESIMS of 5 showed a cluster of isotopic $[\mathrm{M}+\mathrm{H}]^{+}$ion peaks at $\mathrm{m} / z$ 368/370 in a ratio of $\sim 3: 1$, indicating the presence of a chlorine atom in the molecule. The NMR spectra of 5 revealed the presence of five methyls $\left[\delta_{\mathrm{H}} 1.22(6 \mathrm{H}, \mathrm{s}), 1.31(3 \mathrm{H}, \mathrm{s}), 1.39(3 \mathrm{H}, \mathrm{s})\right.$, and $\left.1.65(3 \mathrm{H}, \mathrm{s})\right]$, an olefinic methine $\left[\delta_{\mathrm{H}} 6.37\left(1 \mathrm{H}\right.\right.$, br s), $\delta_{\mathrm{C}} 125.7(\mathrm{CH})$, and $\left.\delta_{\mathrm{C}} 132.4(\mathrm{qC})\right]$, a chlorine-bearing methine $\left[\delta_{\mathrm{H}} 3.93\right.$ $\left.(1 \mathrm{H}, \mathrm{m}) / \delta_{\mathrm{C}} 64.2\right]$, and two oxygenated quaternary carbons $\left(\delta_{\mathrm{C}} 74.2\right.$ and 76.9$)$ for the major s-trans isomer (Tables 1 and 2). Analysis of the 2D NMR (HSQC, HMBC, and COSY) data (Figure 4) revealed that 5 possessed the same carbon skeleton as kalihinene $X(\mathbf{1 1})$ and $Y(12)$ [15].

Figure 4. COSY (-), key HMBC $(\rightarrow)$, and key NOESY correlations of 5.

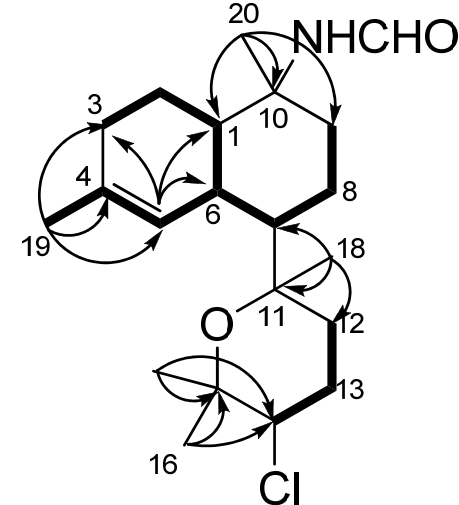

5

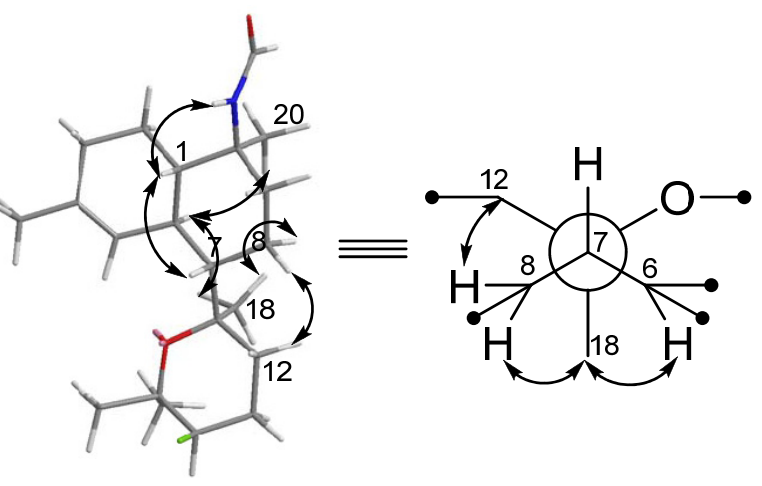


The relative configuration of the decalin ring in $\mathbf{5}$ was the same as $\mathbf{1 2}$, inferred from the chemical shifts of C-1 to C-10 and NOESY correlations of $\mathrm{H}-1 / \mathrm{H}-7, \mathrm{H}_{3}-20 / \mathrm{H}-6$, and $\mathrm{NH} / \mathrm{H}-1$. A significant difference between 5 and 12 was found in the chemical shift of C-12 $\left(\delta_{\mathrm{C}} 31.0\right.$ in $\mathbf{5}$ instead of $\delta_{\mathrm{C}} 38.2$ in 12), which was caused by the $\gamma$-gauche effect [20-24], indicating an axial orientation of $\mathrm{Cl}-14$. The relative configurations of C-7 and C-11 in 5 were determined as $S^{*}$ and $R^{*}$, respectively, from NOESY correlations of $\mathrm{H}_{3}-18 / \mathrm{H}-6, \mathrm{H}_{3}-18 / \mathrm{H}-8 \mathrm{~b}$, and $\mathrm{H}-8 \mathrm{a} / \mathrm{H}-12$, as shown in the Newman projection (Figure 4). Finally, the absolute configuration of 5 was unambiguously determined as $1 S, 6 S, 7 S, 10 S, 11 R$, and $14 R$ by single crystal $\mathrm{X}$-ray diffraction using $\mathrm{Cu} \mathrm{K \alpha}$ radiation (Figure 5).

Figure 5. ORTEP drawing of compound 5.

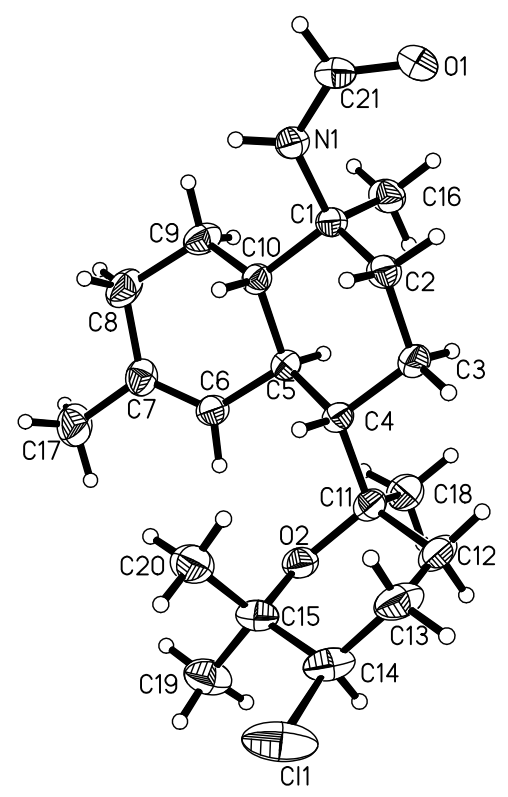

Kalihinene $\mathrm{F}$ (6) was isolated as a colorless oil and given a $\mathrm{C}_{21} \mathrm{H}_{33} \mathrm{NO}_{2}$ molecular formula based on HRESIMS measurements $\left(\mathrm{m} / \mathrm{z} 354.2406[\mathrm{M}+\mathrm{Na}]^{+}\right)$in combination with extensive NMR analysis. The NMR spectra of 6 (Tables 1 and 2) revealed the presence of five methyls $\left[\delta_{\mathrm{H}} 1.18(3 \mathrm{H}, \mathrm{s}), 1.20\right.$ $(3 \mathrm{H}, \mathrm{s}), 1.31(3 \mathrm{H}, \mathrm{s})$, and $1.68(6 \mathrm{H}, \mathrm{s})]$, two trisubstituted double bonds $\left[\delta_{\mathrm{H}} 5.70(\mathrm{br} \mathrm{s}), \delta_{\mathrm{C}} 127.1(\mathrm{CH})\right.$, and $\delta_{\mathrm{C}} 131.1(\mathrm{qC}) ; \delta_{\mathrm{H}} 5.32(\mathrm{br} \mathrm{s}), \delta_{\mathrm{C}} 120.2(\mathrm{CH})$, and $\left.\delta_{\mathrm{C}} 136.9(\mathrm{qC})\right]$, an oxymethine $\left[\delta_{\mathrm{H}} 3.75\right.$ $\left.(\mathrm{t}, J=7.0 \mathrm{~Hz}) / \delta_{\mathrm{C}} 84.2\right]$, and an oxygenated quaternary carbons $\left(\delta_{\mathrm{C}} 86.4\right)$ for the major s-trans isomer. The COSY correlations of $\mathrm{H}_{3}-20 / \mathrm{H}-9 / \mathrm{H}-8 / \mathrm{H}-7 / \mathrm{H}-6 / \mathrm{H}-1 / \mathrm{H}-2 / \mathrm{H}-3$ and $\mathrm{H}-6 / \mathrm{H}-5 / \mathrm{H}_{3}-19$, together with the HMBC correlations of $\mathrm{H}_{3}-19 / \mathrm{C}-3, \mathrm{C}-4$, and C-5, $\mathrm{H}_{3}-20 / \mathrm{C}-1$, C-10, and C-9, H-5/C-1, C-3, and C-6, $\mathrm{H}-2$ and $\mathrm{H}-3 / \mathrm{C}-4$, and $\mathrm{H}-8 / \mathrm{C}-10$ indicated the presence of a decalin moiety (Figure 6 ). A tetrahydrofuran ring, attached to the decalin ring at $\mathrm{C}-7$, was established by carbon resonances at $\delta_{\mathrm{C}} 84.2(\mathrm{C}-14)$ and 86.4 (C-11), COSY correlations of H-12/H-13/H-14, HMBC correlations of $\mathrm{H}_{3}-18 / \mathrm{C}-7$, C-11, and C-12 and geminal methyls $\left(\mathrm{H}_{3}-16\right.$ and $\left.\mathrm{H}_{3}-17\right) / \mathrm{C}-14$ and $\mathrm{C}-15$, and NOESY correlation between $\mathrm{H}_{3}-18$ and $\mathrm{H}-14$. The location of the formamide functionality was assigned to be at $\mathrm{C}-15$ by the observation of doubled singlets for $\mathrm{H}_{3}-16\left[\delta_{\mathrm{H}} 1.31(\mathrm{~s})\right.$ and $1.38(\mathrm{~s})$ for s-trans and s-cis isomers, respectively] and $\mathrm{H}_{3}-17\left[\delta_{\mathrm{H}} 1.20(\mathrm{~s})\right.$ and $1.34(\mathrm{~s})$ for s-trans and s-cis isomers, respectively] and doubled triplets for $\mathrm{H}-14\left[\delta_{\mathrm{H}} 3.75(\mathrm{t}, 7.0)\right.$ and $3.80(\mathrm{t}, 7.0)$ for s-trans and s-cis isomers, respectively] [6]. The relative configuration of 6 was determined by NOESY correlation of H-1/H-6 and carbon resonances at $\delta_{\mathrm{C}} 40.1$ 
(C-1), 36.5 (C-6), and 44.9 (C-7) [6]. NOESY correlations of $\mathrm{H}_{3}-18 / \mathrm{H}-6, \mathrm{H}_{3}-18 / \mathrm{H}-8 \mathrm{~b}$, and $\mathrm{H}-8 / \mathrm{H}-12 \mathrm{~b}$ defined the relative configurations of $7 S^{*}, 11 R^{*}$, as shown in the Newman projection (Figure 6).

Figure 6. COSY $(-)$, key HMBC $(\rightarrow)$, and key NOESY $(\leftrightarrow)$ correlations of 6 .
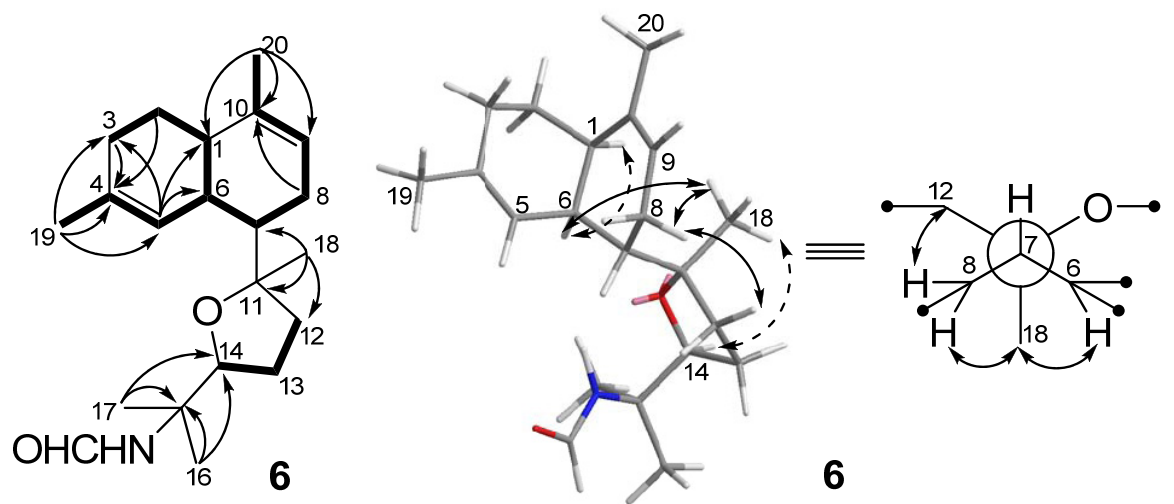

Kalihypyran C (7), a colorless oil, had a molecular formula of $\mathrm{C}_{21} \mathrm{H}_{31} \mathrm{NO}_{2}$ established by HRESIMS at $m / z 352.2255[\mathrm{M}+\mathrm{Na}]^{+}$, indicating seven degrees of unsaturation. Its ${ }^{1} \mathrm{H}$ and ${ }^{13} \mathrm{C} \mathrm{NMR}$ spectra (Tables 1 and 2) showed the presence of three methyls $\left[\delta_{\mathrm{H}} 1.55(3 \mathrm{H}, \mathrm{s}), 1.62(3 \mathrm{H}, \mathrm{s}), 1.78(3 \mathrm{H}, \mathrm{s})\right]$, two trisubstituted double bonds $\left[\delta_{\mathrm{H}} 5.39(\mathrm{br} \mathrm{s}), \delta_{\mathrm{C}} 123.9(\mathrm{CH})\right.$, and $\delta_{\mathrm{C}} 134.5(\mathrm{qC}) ; \delta_{\mathrm{H}} 5.61(\mathrm{br} \mathrm{s}), \delta_{\mathrm{C}} 118.6$ $(\mathrm{CH})$, and $\delta_{\mathrm{C}} 139.0(\mathrm{qC})$ ], a disubstituted double bond [ $\delta_{\mathrm{H}} 4.88(\mathrm{br} \mathrm{s}), 5.01(\mathrm{br} \mathrm{s}), \delta_{\mathrm{C}} 110.5\left(\mathrm{CH}_{2}\right)$, and $\left.\delta_{\mathrm{C}} 145.4(\mathrm{qC})\right]$, an oxymethylene $\left[\delta_{\mathrm{H}} 4.16(\mathrm{~s}, 2 \mathrm{H}) / \delta_{\mathrm{C}} 67.63\right]$, and an oxymethine $\delta_{\mathrm{H}}\left[3.89(\mathrm{br} \mathrm{s}) / \delta_{\mathrm{C}} 77.2\right]$ for $\mathrm{s}$-cis isomer. Many similarities of the ${ }^{1} \mathrm{H}$ and ${ }^{13} \mathrm{C}$ NMR data between 7 and 8 suggested they were structural analogs [16], the COSY correlations of $\mathrm{H}_{3}-19 / \mathrm{H}-5 / \mathrm{H}-6, \mathrm{H}_{3}-17 / \mathrm{H}-16$, and $\mathrm{H}-18 / \mathrm{H}-12 / \mathrm{H}-13 / \mathrm{H}-14$ and the HMBC correlations of $\mathrm{H}_{3}-19 / \mathrm{C}-3, \mathrm{C}-4$, and C-5, $\mathrm{H}_{3}-20 / \mathrm{C}-1$, C-9, and C-10, $\mathrm{H}_{3}-17 / \mathrm{C}-14$, C-15, and $\mathrm{C}-16$, and $\mathrm{H}_{2}-16 / \mathrm{C}-14, \mathrm{C}-15$, and $\mathrm{C}-17$ further confirmed 7 possessed the same carbon skeleton as 8 . The chemical shifts of C-1, C-6, and C-20 for s-trans isomers in 7 ( $\delta_{\mathrm{C}} 45.4,36.6$, and 29.7, respectively) were different from those in $\mathbf{8}\left(\delta_{\mathrm{C}} 48.9,39.4\right.$, and 18.9 , respectively), indicated cis fusion of the decalin ring in 7 [16]. The NOESY correlations of $\mathrm{H}-1 / \mathrm{H}-6, \mathrm{H}-1 / \mathrm{H}_{3}-20$, and $\mathrm{H}-6 / \mathrm{H}_{3}-20$ confirmed the relative configurations as 7 . However, the relative configuration of $\mathrm{H}-14$ was not determined.

The isolated compounds were assessed for their cytotoxicity against a small panel of human cancer cell lines (human colon cancer cell line HCT-116, human lung epithelial cell line A549, human cervical carcinoma cell line HeLa, human hepatocellular carcinoma cell line QGY-7701, and human mammary cancer cell line MDA-MB-231) using a MTT method, and camptothecin (Shanghai Dibai Chemical Co., Shanghai, China; purity $\geq 98 \%$ ) was used as positive control. Compounds 1 and 2 showed moderate cytotoxic activities against HCT-116 with $\mathrm{IC}_{50}$ values of 6.31 and $8.99 \mu \mathrm{M}$, respectively. Compounds 5 showed cytotoxic activity against HCT-116, HeLa, QGY-7701 and MDA-MB-231 with $\mathrm{IC}_{50}$ values of $14.36,13.36,17.78$ and $12.84 \mu \mathrm{M}$, respectively (Table 3). In addition, compounds 1-12 were tested for antifungal activity against fungi Candida albicans, Candida parapsilosis, Candida glabrata, Cryptococcus neoformans, Trichophyton rubrum, Microsporum gypseum, and Aspergillus fumigatus. Compound 9 showed weak antifungal activity against T. rubrum and M. gypseum with MIC values of 8 and $32 \mu \mathrm{g} / \mathrm{mL}$, respectively. Compound 10 displayed weak antifungal activity against fungi C. albicans, C. neoformans, T. rubrum, and M. gypseum with MIC values of $8,8,4$, and $8 \mu \mathrm{g} / \mathrm{mL}$, respectively. Ketoconazole (Shanghai Aiyan 
Chemical Co., Shanghai, China; purity $\geq 98 \%$ ) was used as positive control with MIC value $\leq 0.25 \mu \mathrm{g} / \mathrm{mL}$. It is worth noting that the isonitrile functionalities in the diterpenes play an important role in their antifungal activity.

Table 3. Cytotoxicities of compounds 1-12 in five cancer cell lines.

\begin{tabular}{cccccc}
\hline & \multicolumn{5}{c}{ Cytotoxicity $\mathbf{I C}_{\mathbf{5 0}}(\boldsymbol{\mu M})$} \\
\cline { 2 - 6 } & HCT-116 & A549 & HeLa & QGY-7701 & MDA-MB-231 \\
\hline $\mathbf{1}$ & 6.31 & $>50$ & $>50$ & $>50$ & $>50$ \\
$\mathbf{2}$ & 8.99 & $>50$ & $>50$ & $>50$ & $>50$ \\
$\mathbf{3}$ & $>50$ & $>50$ & $>50$ & $>50$ & $>50$ \\
$\mathbf{4}$ & $>50$ & $>50$ & $>50$ & $>50$ & $>50$ \\
$\mathbf{5}$ & 14.36 & $>50$ & 13.36 & 17.78 & 12.84 \\
$\mathbf{6}$ & $>50$ & $>50$ & $>50$ & $>50$ & $>50$ \\
$\mathbf{7}$ & $>50$ & $>50$ & $>50$ & $>50$ & $>50$ \\
$\mathbf{8}$ & $>50$ & 13.09 & 11.19 & 13.53 & $>50$ \\
$\mathbf{9}$ & $>50$ & 17.53 & 14.74 & 16.39 & $>50$ \\
$\mathbf{1 0}$ & $>50$ & 6.98 & 13.30 & 14.53 & 6.84 \\
$\mathbf{1 1}$ & 12.25 & 8.55 & 10.59 & 13.02 & 7.46 \\
$\mathbf{1 2}$ & $>50$ & 17.12 & 10.05 & 14.41 & 15.23 \\
camptothecin & 9.25 & 2.32 & 6.98 & 4.05 & 0.50 \\
\hline
\end{tabular}

\section{Experimental Section}

\subsection{General Experimental Procedures}

Optical rotation data were determined with a Perkin-Elmer 341 polarimeter (Perkin-Elmer, Inc., Waltham, MA, USA) with a $1 \mathrm{dm}$ cell. UV spectra were collected using a Shimadzu UV 240 spectrophotometer (Shimadzu Corp., Kyoto, Japan). IR spectra were recorded on a Bruker vector 22 spectrometer (Bruker Optics, Inc., Billerica, MA, USA) with $\mathrm{KBr}$ pellets. NMR experiments were conducted on Bruker Avance-500 and AMX-400 spectrometers (Bruker Biospin Corp., Billerica, MA, USA). The HRESIMS spectra were acquired with a Waters Q-Tof micro YA019 mass spectrometer (Waters Corp., Milford, MA, USA). X-ray structure analysis was performed on a Bruker SMART APEX-II CCD diffractometer (Bruker Optics, Inc.). Melting points were obtained on an SGW X-4 melting point apparatus (Shanghai Precision \& Scientific Instrument Co., Ltd, Shanghai, China). Reversed-phase HPLC was carried out on a YMC-Pack ODS-A column $(250 \times 10 \mathrm{~mm}, 5 \mu \mathrm{m}$; YMC Co., Ltd., Kyoto, Japan) using a Waters 1525 HPLC instrument with Waters 2998 UV detector and monitored at $210 \mathrm{~nm}$. Silica gel (200-300 mesh, Qingdao Chengyang Ocean Chemical Co., Jinan, China), Sephadex LH-20 (Pharmacia Fine Chemicals, Piscataway, NJ, USA), and YMC ODS-A (50 $\mu \mathrm{m}$, YMC Co., Ltd, Kyoto, Japan) were used as column packing materials. Fractions were monitored by TLC (HSGF 254, Yantai Huiyou Co., Yantai, China), and spots were visualized by heating silica gel plates sprayed with $12 \% \mathrm{H}_{2} \mathrm{SO}_{4}$ in $\mathrm{EtOH}$. 


\subsection{Animal Material}

Samples of $A$. cavernosa were collected by hand using scuba around Xisha Islets in the South China Sea in March 2009 and identified by Professor Jin-He Li (Institute of Oceanology, Chinese Academy of Sciences, China). A voucher sample (JHQ-0901) was deposited in the Laboratory of Marine Drugs, Department of Pharmacy, Changzheng Hospital, Second Military Medical University, China.

\subsection{Extraction and Isolation}

The sponge $(5.5 \mathrm{~kg}$, wet weight) was extracted with acetone at room temperature five times $(5 \times 5 \mathrm{~L})$ and the extract was concentrated to a brown oil, which was redissolved in $\mathrm{H}_{2} \mathrm{O}(2 \mathrm{~L})$. The aqueous solution was extracted with $\mathrm{CH}_{2} \mathrm{Cl}_{2}(4 \times 2 \mathrm{~L})$ to afford a $\mathrm{CH}_{2} \mathrm{Cl}_{2}$-soluble extract $(89 \mathrm{~g})$. The resulting extract was partitioned between petroleum ether $(4 \times 1 \mathrm{~L})$ and $90 \%$ aqueous $\mathrm{MeOH}(4 \times 1 \mathrm{~L})$ to yield a brownish red oil $(49 \mathrm{~g})$, which was subjected to column chromatography $(80 \times 7.0 \mathrm{~cm})$ on silica gel (1000.5 g) eluting with petroleum ether-acetone gradient (stepwise, 0:1, 50:1, 30:1, 15:1, 8:1, 3:1 to $0: 1,40 \mathrm{~L}$ ), and finally $\mathrm{MeOH}$, to give eight fractions (Fractions 1-8). Fraction 5 (5.4 g) was fractionated over Sephadex LH-20 (40 $\times 2000 \mathrm{~mm}$, eluted with $\left.\mathrm{CH}_{2} \mathrm{Cl}_{2} / \mathrm{MeOH} 1: 1,1.5 \mathrm{~L}\right)$, and further fractionated by CC on ODS (RP-18, $30 \times 500 \mathrm{~mm}$ ), eluted with $70 \%-100 \% \mathrm{MeOH} / \mathrm{H}_{2} \mathrm{O}$, to give four subfractions (Fractions 5a-d). Fraction $5 \mathrm{a}(203.4 \mathrm{mg})$ was purified by HPLC (YMC-Pack ODS-A, $5 \mu \mathrm{m}, 10 \times 250 \mathrm{~mm}, 2.0 \mathrm{~mL} / \mathrm{min}$, UV detection at $210 \mathrm{~nm})$, using $\mathrm{MeOH} / \mathrm{H}_{2} \mathrm{O}(88: 12)$ as eluent, to yield $7\left(2.1 \mathrm{mg}, t_{R}=40.5 \mathrm{~min}\right)$ and $\mathbf{8}\left(4.2 \mathrm{mg}, t_{R}=42.5 \mathrm{~min}\right)$. Fraction $5 \mathrm{~b}(659 \mathrm{mg})$ was subjected to $\mathrm{CC}(15 \times 300 \mathrm{~mm})$ on silica gel $(15 \mathrm{~g})$, using $\mathrm{CH}_{2} \mathrm{Cl}_{2} / \mathrm{MeOH}$ with increasing polarity $(1: 0,100: 1,50: 1)$ as mobile phase, to yield compound $4(13.3 \mathrm{mg})$. Fraction $5 \mathrm{c}(368.0 \mathrm{mg})$ was purified by HPLC (YMC-Pack ODS-A, $5 \mu \mathrm{m}, 10 \times 250 \mathrm{~mm}, 2.0 \mathrm{~mL} / \mathrm{min}$, UV detection at $210 \mathrm{~nm}$ ), using $\mathrm{MeOH} / \mathrm{H}_{2} \mathrm{O}(92: 8)$ as eluent, to afford $\mathbf{1}$ (48.9 $\left.\mathrm{mg}, t_{R}=36.6 \mathrm{~min}\right), \mathbf{3}\left(4.2 \mathrm{mg}, t_{R}=40.8 \mathrm{~min}\right)$, and 2 (50.7 $\left.\mathrm{mg}, t_{R}=43.8 \mathrm{~min}\right)$. Fraction 5d $(267.5 \mathrm{mg})$ was chromatographied $(15 \times 300 \mathrm{~mm})$ on silica gel $(15 \mathrm{~g}$, eluted with $\left.\mathrm{CH}_{2} \mathrm{Cl}_{2} / \mathrm{MeOH} 50: 1\right)$, to obtain $10(160 \mathrm{mg})$. Fraction $6(7.4 \mathrm{~g})$ was applied to Sephadex LH-20 $(40 \times 2000 \mathrm{~mm})$ eluted with $\mathrm{CH}_{2} \mathrm{Cl}_{2} / \mathrm{MeOH}(1: 1)$ to furnish three subfractions (Fractions $6 \mathrm{a}$ and $\mathrm{c}$ ). Fraction $6 \mathrm{~b}(1.3 \mathrm{~g})$ was subjected to CC on ODS (RP-18, $30 \times 500 \mathrm{~mm})$, eluting with $80 \%-100 \%$ $\mathrm{MeOH}$, to give five subfractions (Fractions 6b1-5). Fraction $6 \mathrm{~b} 2(123 \mathrm{mg}$ ) was purified by HPLC (YMC-Pack ODS-A, $5 \mu \mathrm{m}, 10 \times 250 \mathrm{~mm}, 2.0 \mathrm{~mL} / \mathrm{min}$, UV detection at $210 \mathrm{~nm}$ ) using $\mathrm{MeOH} / \mathrm{H}_{2} \mathrm{O}(92: 8)$ as eluent to $9\left(1.0 \mathrm{mg}, t_{R}=37.5 \mathrm{~min}\right)$. Fraction $6 \mathrm{~b} 3(31.5 \mathrm{mg})$ was fractioned by a Sephadex LH-20 column $(15 \times 2000 \mathrm{~mm})$ eluting with hexane $/ \mathrm{CH}_{2} \mathrm{Cl}_{2} / \mathrm{MeOH}(5: 4: 1)$ to afford 6 (4.5 mg). Compound 5 (50.9 mg) was obtained from fraction $6 \mathrm{~b} 4(478.5 \mathrm{mg})$ by a $\mathrm{CC}(15 \times 300 \mathrm{~mm})$ on silica gel $(15 \mathrm{~g}$, eluted with $\left.\mathrm{CH}_{2} \mathrm{Cl}_{2} / \mathrm{MeOH} 30: 1\right)$. Fraction 7 (8.3 g) was subjected to $\mathrm{CC}(40 \times 2000 \mathrm{~mm})$ on Sephadex LH-20 eluting with $\mathrm{MeOH}$ followed by HPLC purification (YMC-Pack ODS-A, $5 \mu \mathrm{m}, 10 \times 250 \mathrm{~mm}$, $2.0 \mathrm{~mL} / \mathrm{min}$, UV detection at $210 \mathrm{~nm}$ ) using $\mathrm{MeOH} / \mathrm{H}_{2} \mathrm{O}(90: 10)$ as eluent to yield 11 (201.5 mg, $\left.t_{R}=50.4 \mathrm{~min}\right)$ and $12\left(197.6 \mathrm{mg}, t_{R}=56.8 \mathrm{~min}\right)$.

Cavernene A (1): colorless oil; $[\alpha]_{\mathrm{D}}^{20}+25.0(c 0.06, \mathrm{MeOH}) ; \mathrm{UV}\left(\mathrm{CH}_{3} \mathrm{CN}\right) \lambda_{\max }(\log \varepsilon)<200(2.45) \mathrm{nm}$; IR $(\mathrm{KBr}) v_{\max } 3323,3051,2927,2856,1670,1541,1457,1386 \mathrm{~cm}^{-1} ;{ }^{1} \mathrm{H}$ and ${ }^{13} \mathrm{C} \mathrm{NMR}$ data, see Tables 1 and 2; HRESIMS $m / z$ 338.2461 [M Na $]^{+}$(calcd for $\mathrm{C}_{21} \mathrm{H}_{33} \mathrm{NONa}, 338.2460$ ). 
Cavernene B (2): colorless oil; $[\alpha]_{\mathrm{D}}^{20}+46.2($ c 0.07, $\mathrm{MeOH}) ; \mathrm{UV}\left(\mathrm{CH}_{3} \mathrm{CN}\right) \lambda_{\max }(\log \varepsilon)<200(2.79)$, 234 (sh, 2.25) nm; IR (KBr) $v_{\max }$ 3295, 3053, 2960, 2926, 2869, 1681, 1537, 1453, $1382 \mathrm{~cm}^{-1}$; ${ }^{1} \mathrm{H}$ and ${ }^{13} \mathrm{C}$ NMR data, see Tables 1 and 2; HRESIMS $m / z 340.2617[\mathrm{M}+\mathrm{Na}]^{+}$(calcd for $\left.\mathrm{C}_{21} \mathrm{H}_{35} \mathrm{NONa}, 340.2616\right)$.

Cavernene C (3): white needles $(\mathrm{MeOH})$; m.p. 98.0-102.0 ${ }^{\circ} \mathrm{C} ;[\alpha]_{\mathrm{D}}^{20}+20.0(c 0.03, \mathrm{MeOH}) ; \mathrm{UV}$ $\left(\mathrm{CH}_{3} \mathrm{CN}\right) \lambda_{\max }(\log \varepsilon)<200(2.95) \mathrm{nm}$; IR $(\mathrm{KBr}) v_{\max } 3304,3062,2958,2926,2855,1668,1538,1455$, $1381 \mathrm{~cm}^{-1}$; ${ }^{1} \mathrm{H}$ and ${ }^{13} \mathrm{C}$ NMR data, see Tables 1 and 2; HRESIMS $m / z 340.2614[\mathrm{M}+\mathrm{Na}]^{+}$(calcd for $\left.\mathrm{C}_{21} \mathrm{H}_{35} \mathrm{NONa}, 340.2616\right)$.

Cavernene D (4): colorless needles $(\mathrm{MeOH})$; m.p. $112.0-115.0{ }^{\circ} \mathrm{C} ;[\alpha]_{\mathrm{D}}^{20}+51.4($ c $0.04, \mathrm{MeOH})$; $\mathrm{UV}\left(\mathrm{CH}_{3} \mathrm{CN}\right) \lambda_{\max }(\log \varepsilon)<200(2.88) \mathrm{nm}$; IR $(\mathrm{KBr}) v_{\max } 3296,3055,2928,2857,1681,1538,1453$, $1383 \mathrm{~cm}^{-1}$; ${ }^{1} \mathrm{H}$ and ${ }^{13} \mathrm{C}$ NMR data, see Tables 1 and 2; HRESIMS $m / z 354.2407[\mathrm{M}+\mathrm{Na}]^{+}$(calcd for $\mathrm{C}_{21} \mathrm{H}_{33} \mathrm{NO}_{2} \mathrm{Na}$, 354.2409).

Kalihinene E (5): colorless needles (MeOH); m.p. $185.0-190.0{ }^{\circ} \mathrm{C} ;[\alpha]_{\mathrm{D}}^{20}+25.0(c 0.04, \mathrm{MeOH}) ; \mathrm{UV}$ $\left(\mathrm{CH}_{3} \mathrm{CN}\right) \lambda_{\max }(\log \varepsilon)<200(2.94) \mathrm{nm} ; \mathrm{IR}(\mathrm{KBr}) v_{\max } 3295,3074,2929,2868,1682,1541,1451$, $1381 \mathrm{~cm}^{-1} ;{ }^{1} \mathrm{H}$ and ${ }^{13} \mathrm{C}$ NMR data, see Tables 1 and 2; HRESIMS $m / z 368.2354[\mathrm{M}+\mathrm{H}]^{+}$(calcd for $\left.\mathrm{C}_{21} \mathrm{H}_{35} \mathrm{NO}_{2} \mathrm{Cl}, 368.2356\right)$.

Kalihinene F (6): colorless oil; $[\alpha]_{\mathrm{D}}^{20}+2.5$ (c 0.08, MeOH); UV $\left(\mathrm{CH}_{3} \mathrm{CN}\right) \lambda_{\max }(\log \varepsilon)<200(2.63)$, $232(\mathrm{sh}, 2.12) \mathrm{nm}$; IR (KBr) $v_{\max } 3216,3057,2966,2929,1686,1451,1379,1311 \mathrm{~cm}^{-1} ;{ }^{1} \mathrm{H}$ and ${ }^{13} \mathrm{C}$ NMR data, see Tables 1 and 2; HRESIMS $m / z$ 354.2406 [M+Na] (calcd for $\mathrm{C}_{21} \mathrm{H}_{33} \mathrm{NO}_{2} \mathrm{Na}, 354.2409$ ).

Kalihipyran C (7): colorless oil; $[\alpha]_{\mathrm{D}}^{20}+24.6(c$ 0.07, $\mathrm{MeOH}) ; \mathrm{UV}\left(\mathrm{CH}_{3} \mathrm{CN}\right) \lambda_{\max }(\log \varepsilon)<200(2.87) \mathrm{nm}$; IR (KBr) $v_{\max } 3296,3055,2925,2855,1668,1537,1454,1377 \mathrm{~cm}^{-1} ;{ }^{1} \mathrm{H}$ and ${ }^{13} \mathrm{C}$ NMR data, see Tables 1 and 2; HRESIMS $m / z 352.2255[\mathrm{M}+\mathrm{Na}]^{+}$(calcd for $\mathrm{C}_{21} \mathrm{H}_{31} \mathrm{NO}_{2} \mathrm{Na}, 352.2252$ ).

X-ray Crystallographic Analysis Data of Kalihinene E (5): Colorless needles, $\mathrm{C}_{21} \mathrm{H}_{34} \mathrm{NO}_{2} \mathrm{Cl}$, $M W=367.94$, monoclinic space group $P 2_{1}, a=6.499$ (2) $\AA, b=7.952$ (2) $\AA, c=20.158$ (4) $\AA$, $\mathrm{V}=1036.1$ (4) $\AA 3, Z=2, D_{\text {calcd }}=1.179 \mathrm{~g} / \mathrm{cm}^{3}$, and $F(000)=400$. A single crystal of dimensions $0.05 \times 0.13 \times 0.18 \mathrm{~mm}$ was used for X-ray measurements and data collected on a Bruker SMART APEX-II CCD diffractometer using $\mathrm{Cu} \mathrm{K} \alpha$ radiation and up to $\theta=67.3$ at $293 \mathrm{~K}$. A total of 5789 reflections were collected, of which 3435 independent reflections were measured having an Rint of 0.0220 , final R indices of $I>2 \sigma(I), \mathrm{R} 1=0.0426, \mathrm{wR} 2=0.1163, \mathrm{R}$ indices for all data $\mathrm{R} 1=0.0445$, and $\mathrm{wR} 2=0.1184$. The crystal structure solution was achieved using direct methods, as implemented with the SHELX-97 software program. The refinment method was full-matrix least-square on $F^{2}$, goodness-of-fit on $F^{2}$ was 1.042 , and the largest difference peak and hole were 0.237 and -0.196 e. $\AA$-3. The absolute structure was determined giving a Flack parameter of 0.07 (2). The X-ray diffraction material has been deposited in the Cambridge Crystallographic Data Center (CCCD No. 847695).

\subsection{Cytotoxicity Assay}

Cytotoxic activity was evaluated by a MTT method as described previously [25]. Cells were cultured in RPMI-1640 supplemented with $10 \%$ fetal bovine serum in $5 \% \mathrm{CO}_{2}$ at $37{ }^{\circ} \mathrm{C}$. An aliquot 
$(200 \mu \mathrm{L})$ of these cell suspensions at a density of $5 \times 10^{-4}$ cell $\mathrm{mL}^{-1}$ was plated in 96 -well microtiter plates and incubated for $24 \mathrm{~h}$ under the above conditions. $2 \mu \mathrm{L}$ of the test compound in DMSO at different concentrations was added to each well for $48 \mathrm{~h}$, and then incubated with $1 \mathrm{mg} / \mathrm{mL}$ MTT for $4 \mathrm{~h}$. The formazan dye product was measured by the absorbance at $570 \mathrm{~nm}$ on a microplate reader. $\mathrm{IC}_{50}$ values were calculated by Reed and Muench's method.

\subsection{Antifungal Activity Assay}

Antifungal activity was determined by the broth macrodilution method following the National Center for Clinical Laboratory Standards (NCCLS) recommendations against the following strains: Candida albicans, Candida parapsilosis, Candida glabrata, Cryptococcus neoformans, Trichophyton rubrum, Microsporum gypseum, and Aspergillus fumigates [26,27]. Briefly, bacterial strains were grown aerobically at $30^{\circ} \mathrm{C}$ in SDA for $16-20 \mathrm{~h}$ in an orbital shaker. A set of tube swith different concentrations of compounds 1-12 prepared in RPMI 1640 were next inoculated with the microorganisms and incubated $24 \mathrm{~h}$ for C. albicans, C. parapsilosis, C. glabrata, and A. fumigatus, $72 \mathrm{~h}$ for C. neoformans, and 4-7 days for T. rubrum and M. gypseum. Broth tubes that appeared turbid were indicative of bacterial growth, while tubes that remained clear indicated no growth. The MIC, defined as the lowest concentration of inhibitory compound at which no growth was observed, was evaluated in triplicate for each compound (within the range $1.25-640 \mu \mathrm{g} / \mathrm{mL}$ ). Cultures prepared under the same conditions but without compounds and cultures with the same proportions of DMSO $(<1 \%)$ were used as controls. The growth of broth tubes without turbidity was further examined by counting the viable cells on the SDA plates.

\section{Conclusions}

A chemical investigation of the marine sponge of Acanthella cavernosa led to the isolation of seven new fomamido-diterpenes, cavernenes A-D (1-4), kalihinenes E and F (5,6), and kalihipyran C (7), and five known compounds, kalihipyran A (8), 15-formamido-kalihinene (9), 10-formamido-kalihinene (10), and kalihinenes X (11) and Y (12). The absolute configuration of 5 was determined by single X-ray diffraction. The isolated compounds showed modest cytotoxicity against a small panel of human cancer cell lines, HCT-116, A549, HeLa, QGY-7701 and MDA-MB-231. Compounds 9 and 10 displayed antifungal activity against Trichophyton rubrum and Microsporum gypseum, Candida albicans, and Cryptococcus neoformans.

\section{Acknowledgments}

We would like to thank Jin-He Li of the Institute of Oceanology, Chinese Academy of Sciences for his help in identifying the marine sponges. This work was funded by the National Natural Science Foundation of China (Nos. 81072573, 81172978, 41106127, and 81001394), the National Science \& Technology Major Project of China (No. 2009ZX09103-427), and the Major Program of Modernization of Chinese Medicine (STCSM, 09dZ1975800). Financial support from the National High Technology Research and Development Program of China (863 Project, 2011AA09070107) is gratefully acknowledged. 


\section{References}

1. Chang, C.W.J.; Patra, A.; Baker, J.A.; Scheuer, P.J. Kalihinols, multifunctional ditepenoid anntibiotics from marine sponges Acanthella spp. J. Am. Chem. Soc. 1987, 109, 6119-6123.

2. Trimurtulu, G.; Faulkner, D.J. Six new ditepene isonitriles from the sponge Acanthella cavernosa. J. Nat. Prod. 1994, 57, 501-506.

3. Clark, R.J.; Stapleton, B.L.; Garson, M.J. New isocyano and isothiocyanato terpene metabolites from the topical marine sponge Acanthella cavernosa. Tetrahedron 2000, 56, 3071-3076.

4. Angerhofer, C.K.; Pezzuto, J.M. Antimalarial activity of sesquiterpenes from the marine sponge Acanthella klethra. J. Nat. Prod. 1992, 55, 1787-1789.

5. Jumaryatno, P.; Stapleton, B.L.; Hooper, J.N.A.; Brecknell, D.J.; Blanchfield, J.T.; Garson, M.J. A comparison of sesquiterpene scaffolds across different populations of the tropical marine sponge Acanthella cavernosa. J. Nat. Prod. 2007, 70, 1725-1730.

6. Rodriguez, J.; Nieto, R.M.; Huter, L.M.; Diaz, M.C.; Crews, P. Variation among known kalihinol and new kalihinene diterpenes from the sponge Acanthella cavernosa. Tetrahedron 1994, 50, 11079-11090.

7. Sun, J.Z.; Chen, K.S.; Yao, L.G.; Liu, H.L.; Guo, Y.W. A new kalihinol diterpene from the hainan sponge Acanthella sp. Arch. Pharm. Res. 2009, 32, 1581-1584.

8. Fusetani, N.; Yasumura, E.; Kawai, H.; Natori, T.; Binnen, L.; Clardy, J. Kalihinene and isokalihinol B, cytotoxic diterpene isonitriles from the marine sponge Acanthella klethra. Tetrahedron Lett. 1990, 31, 3559-3602.

9. Omar, S.; Albert, C.; Fanni, T.; Crews, P. Polyfunctional diterpene isonitriles from marine sponge Acanthella cavernosa. J. Org. Chem. 1988, 53, 5971-5972.

10. Alvi, K.A.; Tenenbaum, L.; Crews, P. Anthelmintic polyfunctional nitrogen-containing terpenoids from marine sponges. J. Nat. Prod. 1991, 54, 71-78.

11. Miyaoka, H.; Shimomura, M.; Kimura, H.; Yamada, Y. Antimalarial activity of kalihinol A and new relative diterpenoids from the Okinawan sponge, Acanthella sp. Tetrahedron 1998, 54, 13467-13474.

12. Bugni, T.S.; Singh, M.P.; Chen, L.; Arias, D.A.; Harper, M.K.; Greenstein, M.; Maiese, W.M.; Concepcion, G.P.; Mangalindan, G.C.; Ireland, C.M. Kalihinols from two Acanthella cavernosa sponges: Inhibitors of bacterial folate biosynthesis. Tetrahedron 2004, 60, 6981-6988.

13. Chang, C.W.J.; Patra, A.; Roll, D.M.; Scheuer, P.J. Kalihinol-A, a highly functionalized diisocyano diterpenoid antibiotic from a sponge. J. Am. Chem. Soc. 1984, 106, 4644-4646.

14. Patra, A.; Chang, C.W.J.; Scheuer, P.A.; Van Dayne, D.G.; Matsumoto, G.K.; Clardy, J. An unprecedented triisocyano diterpenoid antibiotic from a sponge. J. Am. Chem. Soc. 1984, 106, 7981-7983.

15. Okino, T.; Yoshimura, E.; Hirota, H.; Fusetani, N. Antifouling kalihinenes from the marine sponge Acanthella cavernosa. Tedrahedron Lett. 1995, 36, 8637-8640.

16. Okino, T.; Yoshimura, E.; Hirota, H.; Fusetani, N. New antifouling kalihipyrans from the marine sponge Acanthella cavernosa. J. Nat. Prod. 1996, 59, 1081-1083.

17. Hirota, H.; Tomono, Y.; Fusetani, N. Terpenoids with antifouing activity against Barnacle larvae from the marine sponge Acanthella cavernosa. Tetrahedron 1996, 52, 2359-2368. 
18. Xu, Y.; Li, N.; Jiao, W.H.; Wang, R.P.; Peng, Y.; Qi, S.H.; Song, S.J.; Chen, W.S.; Lin, H.W. Antifouling and cytotoxic constituents from the South China Sea sponge Acanthella cavernosa. Tetrahedron 2012, 6, 2876-2883.

19. Garson, M.J.; Simpson, J.S. Marine isocyanides and related natural products-Structure, biosynthesis and ecology. Nat. Prod. Rep. 2004, 21, 164-179.

20. Dorman, D.E.; Roberts, J.D. Nuclear magnetic resonance spectroscopy. Carbon-13 spectra of some pentose and hexose aldopyranoses. J. Am. Chem. Soc. 1970, 92, 1355-1361.

21. Dalling, D.K.; Grant, D.M. Carbon-13 magnetic resonance. IX. The methylcyclohexanes. J. Am. Chem. Soc. 1967, 89, 6612-6622.

22. Ribeiro, D.S.; Olivato, P.R.; Rittner, R. Axial/equatorial populations in $\alpha$-hetero-substituted cyclohexanone Oximes and $O$-methyl oximes. Magn. Reson. Chem. 2000, 38, 627-638.

23. Gultekin, D.D.; Tasxkesenligil, Y.; Dastan, A.; Balci, M. Bromination of norbornene derivatives: Synthesis of brominated norbornanes and norbornenes. Tetrahedron 2008, 64, 4377-4383.

24. Tonelli, A.E.; Schilling, F.C. ${ }^{13} \mathrm{C}$ NMR chemical shifts and the microstructure of propylene-vinyl chloride copolymers with low propylene content. Macromolecules 1984, 17, 1946-1949.

25. Zhang, H.J.; Yi, Y.H.; Yang, G.J.; Hu, M.Y.; Cao, G.D.; Yang, F.; Lin, H.W. Proline-containing cyclopeptides from the marine sponge Phakellia fusca. J. Nat. Prod. 2010, 73, 650-655.

26. Clinical and Laboratory Standards Institute. Reference Method for Broth Dilution Antifungal Susceptibility Testing of Filamentous Fungi: Approved Standard; NCCLS M38-A2; Clinical Laboratory Standards Institute: Wayne, PA, USA, 2008.

27. Clinical and Laboratory Standards Institute. Reference Method for Broth Dilution Antifungal Susceptibility Testing of Yeasts: Approved Standard; NCCLS M27-A3; Clinical and Laboratory Standards Institute: Wayne, PA, USA, 2009.

Samples Availability: Available from the authors.

(C) 2012 by the authors; licensee MDPI, Basel, Switzerland. This article is an open access article distributed under the terms and conditions of the Creative Commons Attribution license (http://creativecommons.org/licenses/by/3.0/). 